\title{
Kajian Ikonografi Pada Seni Lukis T-Shirt Tema Rangda Karya I Nyoman Ngurah Ardika Yasa
}

\author{
I Wayan Swandi', Arya Pageh Wibawa ${ }^{2}$, I Gusti Ngurah Agung Mahaputra ${ }^{3}$ \\ ${ }^{1,2,3}$ Program Studi Desain Komunikasi Visual, Fakultas Seni Rupa dan Desain, \\ Institut Seni Indonesia Denpasar \\ ${ }^{1}$ wayanswandi@gmail.com
}

Bali telah dikenal memiliki banyak bentuk seni. Salah satunya adalah seni lukis. Seni Lukis di Bali telah dikenal cukup lama. Seiring perjalanan waktu, terjadi perubahan dengan kedatangan bangsa Barat yang mempengaruhi gaya lukis Bali. Selanjutnya, media juga memberikan pengaruh yang sangat besar dalam seni lukis di Bali, salah satunya adalah t-shirt. Salah satu seniman lukis t-shirt yang cukup dikenal oleh anak muda Bali yaitu I Nyoman Ngurah Ardika Yasa. Pada karyanya yang bertema "Rangda", salah satu dari banyak karya yang telah dibuat cukup menarik untuk dilakukan penelitian. Metode yang digunakan dalam penelitian ini adalah metode ikonografi Erwin Panofsky. Tujuan penelitian ini adalah untuk mengetahui makna karya seni lukis t-shirt seniman I Nyoman Ngurah Ardika yang bertemakan rangda.Tahap pra-ikonografi, ilustrasi yang digambarkan merupakan sebuah komunikasi bahwa rangda merupakan sosok yang akan membawa kematian bagi manusia. Pada tahapan analisis ikonografi digunakan teori Roland Barthes untuk mengungkap lambang yang ada pada karya tersebut. Mitos yang hadir sebagai petanda dalam karya selanjutnya dihubungkan dengan tema dan konsep yang tersirat. "Rangda" telah menjadi mitos yang ada pada masyarakat Bali. Analisis interpretasi ikonologis, Ilustrasi rangda karya I Nyoman Ngurah Ardika Yasa diciptakan tidak dengan mengedepankan nilai keindahan secara konvensional, namun berdasarkan imajinasi atas rasa dan pengalaman estetis yang diterima pada masa yang lalu. Pada karyanya wujud rangda digambarkan dengan penggayaan bentuk melalui penyederhaan dan deformasi bentuk, sehingga karakter rangda terlihat berbeda dengan wujud rangda secara tradisi. Sehingga dapat dikatakan bahwa ilustrasi rangda ini mengikuti gaya postmodern champ yaitu menolak keotentikan atau keorisinilan untuk tujuan dan kepentingannya sendiri.

Kata kunci : rangda, ikonografi, erwin panofsky, t-shirt painting, i nyoman ngurah ardika yasa

\section{Research Of Arts Painting On T-Shirt With Theme Of Rangda Working By Artist I Nyoman Ngurah Ardika Yasa Using Iconography}

Bali has had many forms of art. One of them is painting. Balinese Painting has been known for a long time. Over time though, they changed when The westerners were arriving that influenced the style of Balinese painting. Furthermore, the media also gave a huge influence in Balinese painting, one of them was a t-shirt. One of the t-shirt painting artists is known by young Balinese, I Nyoman Ngurah Ardika Yasa. In his work entitled "Rangda", one of his works has been made, is interesting enough to do research. The method of this research is the iconographic method of Erwin Panofsky. The purpose of this study was to find out the meaning of t-shirt painting of I Nyoman Ngurah Ardika Yasa with the theme of rangda. In the pre-iconography stage, the illustration is depicted revealing a communication that Rangda is a person who would bring death to humans. At the stage of iconographic analysis, Roland Barthes's theory was used to reveal the symbols in the work. The myths that are present as markers in the work are then related to the implicit themes and concepts. "Rangda" has become a myth that exists in Balinese society. Analysis of iconological interpretations, I Nyoman Ngurah Ardika Yasa's illustration of rangda were not created with prioritizing the value of beauty in a conventional way, but it based on imagination over the aesthetic taste and experience that had received in the past. In his work, the rangda is depicted in the form of simplification and deformation, so that the character of Rangda looks different from the traditional form. So, it can be said that the illustration of Rangda following a postmodern style is a champ that rejects authenticity for its own purposes and interests.

Keywords: rangda, iconography, erwin panofsky, t-shirt painting, i nyoman ngurah ardika yasa 


\section{LATAR BELAKANG}

Bali telah dikenal memiliki banyak bentuk seni. Salah satunya adalah seni lukis. Seni lukis Bali telah berkembang cukup lama. Pada awalnya, seni lukis Bali tidak mengenal lukisan komersial, lukisan pada waktu itu semata-mata digunakan sebagai hiasan yang ditempatkan pada tempat-tempat pertunjukan, istana-istana bangsawan dan pura-pura baik sebagai umbul-umbul, kober, langse dan ider-ider. Para seniman tidak menjual hasil karyanya kepada masyarakat umum. Para seniman ini dijamin hidupnya oleh keluarga raja dan para bangsawan dengan memberikan pekerjaan yang tetap yaitu menghias berbagai istana dan tempat ibadah yang dibangun. Bahkan ada sebuah desa di selatan kota Semarapura kabupaten Klungkung yaitu desa Kamasan yang hampir seluruh penduduknya berprofesi sebagai pelukis sejak jaman kerajaan hingga saat ini. Penduduk desa Kamasan memiliki profesi sebagai pelukis yang bekerja pada raja Klungkung.

Sebelum tahun 1920-an, lukisan tradisional Bali dibatasi pada wayang dengan menggunakan gaya kamasan. Narasi yang dihadirkan merupakan cerita epik Ramayana dan Mahabharata versi Hindu-Jawa serta cerita loka seperti panji. Penggunaan warna alam seperti merah, oker, hitam dan lain-lain memiliki keterbatasan ditambah lagi dengan aturan-aturan yang ketat dalam penggunaan ornamen akibat sebagian produksi digunakan untuk agama dan hiasan candi, membuat seni lukis tradisi sulit berkembang.

Selanjutnya dengan hadirnya pengaruh barat, perkembangan seni lukis Bali mulai nampak. Munculnya kelompok "Pita Maha" yang dipelopori oleh Spies, Bonnet, Cokorde Raka Sukawati, dan Gusti Nyoman Lempad pada tahun 1974 menjadi titik tolak perkembangan seni lukis modern di Bali. Seniman yang bergabung dengan kekuatan masing-masing bersatu untuk mendidik seniman lokal. Satu hal yang menonjol dari kelompok "Pita Maha" ini adalah pemilihan tema yang sudah melepaskan diri dari tradisi dan pewayangan menjadi lingkungan dan kondisi sekitarnya. Sebagai akibatnya muncul berbagai gaya lukisan seperti Batuan, Ubud, dan gaya Young Artist dengan tokohnya Arie Smith.

Saat ini perkembangan media sudah begitu pesatnya membuat seni lukis mulai melirik media lain yang dapat digunakan untuk menampilkan ekspresi dari karya-karya mereka. Salah satunya adalah $t$-shirt. Pada awalnya, t-shirt digunakan sebagai media alternatif oleh seniman lukis sekaligus praktis dalam upayanya untuk menghias. Dalam perkembangannya, media t-shirt semakin diminati dengan mengangkat tema-tema seperti hewan, tumbuhan, pemandangan dan bahkan potret wajah. Seiring dengan perkembangan dari bahan cat yang digunakan untuk melukis pada t-shirt, posisi melukis pada media t-shirt semakin menampakkan kelasnya tersendiri. Sebelum adanya t-shirt lukis, sablon merupakan pilihan utama dalam berkarya un- tuk memberikan nilai tambah dan menjadikan t-shirt lebih menarik.

Salah satu seniman lukis t-shirt yang cukup dikenal oleh anak muda Bali yaitu I Nyoman Ngurah Ardika Yasa atau biasa dipanggil dengan Jombol. Sejak kecil, I Nyoman Ngurah Ardika Yasa merupakan sosok anak yang sangat menggemari dunia seni, khususnya seni menggambar. I Nyoman Ngurah Ardika Yasa mulai menekuni kegemarannya melukis pada media t-shirt secara profesional sejak tahun 2013 dan hingga kini telah banyak karya dibuatnya. I Nyoman Ngurah Ardika Yasa yang bertempat tinggal dan sekaligus menjadi studio untuk memasarkan produk hasil karyanya di jalan arja no. 11, banjar belawan abian semal Badung telah mengirimkan pesanan t-shirt seni lukisnya ke Yogyakarta, Surabaya, Jakarta, Lampung, Sulawesi, dan Lombok. Selain itu, produksi seni lukis t-shirtnya juga diminati oleh masyarakat luar negeri seperti Amerika, Australia, Malaysia, dan Singapura. I Nyoman Ngurah Ardika Yasa juga kerap mengikuti pameran lokal maupun nasional dan workshop tentang $t$-shirt lukis antara lain Home Industri di Jakarta (2016), Pordes Desa Ubud (2017), Workshop t-shirt lukis Bali di Blahbatuh (2017), Sanur Festival (2017), hut Kabupaten Badung (2017) dan 2018), Bulan Bakti Gotong Royong Desa Blahkiuh (2018) dan mengikuti pameran bareng Komunitas yang bertemakan kearifan lokal Bali.

I Nyoman Ngurah Ardika Yasa banyak mengambil inspirasi dari dunia keseharian dan cerita-cerita kedaerahan. Menurutnya, budaya Bali menjadi inspirasi dalam karyakarya lukis t-shirt yang dibuatnya seperti Rangda, Barong, Celuluk, dan topeng sidakarya. I Nyoman Ngurah Ardika Yasa tampil dengan objek yang lebih menekankan pada kemistisan dan sangat menyukai dunia niskala dalam setiap karya-karyanya. I Nyoman Ngurah Ardika Yasa juga mengakui bahwa kegemarannya dengan dunia niskala menjadikan inspirasi seni lukis t-shirt yang dibuatnya memiliki karakteristik ilustrasi yang berbeda. Selain itu, karya ilustrasi t-shirt yang dibuatnya memberikan sebuah ciri khas tersendiri yang berbeda dengan karya orang lain. Kelebihan I Nyoman Ngurah Ardika Yasa adalah lebih menekankan pada keindahan budaya Bali dengan mengangkat hal-hal berbau mistis untuk menghindari kebosanan atas penyeragaman bentuk. Ilustrasi rangda karya I Nyoman Ngurah Ardika Yasa divisualisasikan dengan menggunakan gaya yang sangat dipengaruhi oleh budaya postmodern. Hal ini yang menjadikan I Nyoman Ngurah Ardika Yasa sebagai objek penelitian dikarenakan keunikan yang dimiliki I Nyoman Ngurah Ardika Yasa pada karya-karya seni lukis t-shirt. Tidak banyak seniman lukis t-shirt yang mau mengangkat budaya Bali terutama hal-hal mistis. Oleh sebab itu, penelitian ini menarik untuk dilakukan terutama melihat makna dari karya seni lukis t-shirt dengan tema rangda dari I Nyoman Ngurah Ardika Yasa. Gaya lukisan yang dimiliki I Nyoman Ngurah Ardika Yasa sangat khas dan berbeda dengan seniman-seniman 
lainnya.

\section{METODE PENELITIAN}

Metodologi yang digunakan dalam penelitian ini adalah deskriptif kualitatif dengan menggunakan analisa teori ikonografi dan ikonologi Erwin Panofsky. Erwin Panofsky dalam bukunya "Meaning in The Visual Arts" (1955) menyampaikan bahwa untuk meneliti dan memahami suatu karya seni bisa dilakukan dengan pendekatan sejarah melalui tiga tahapan yaitu pra ikonografi (pre iconographical description), analisis ikonografi (iconographical analysis) dan interpretasi ikonologis (iconological interpretation) (Panofsky, 1955:26-40). Pra ikonografi menekankan pada pembacaan objek secara formal yaitu teknik, gaya, dan medium perancangan. Analisis ikonografi lebih pada eksplorasi tentang gaya perancangan dan narasi. MnSementara tahap ikonologi merupakan tahap pemahaman mengenai makna yang terdapat pada sebuah objek. Untuk melihat secara keseluruhan dapat dilihat pada gambar dibawah ini :

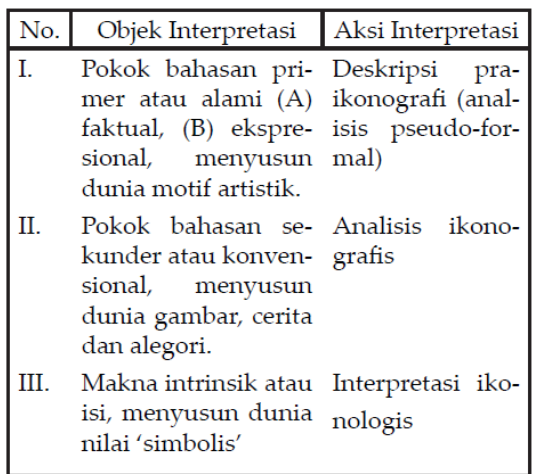

\begin{tabular}{|c|c|}
\hline Alat Interpretasi & $\begin{array}{l}\text { Prinsip Korektif dari } \\
\text { Interpretasi (Sejarah } \\
\text { Tradisi) }\end{array}$ \\
\hline $\begin{array}{l}\text { Pengalaman praktis } \\
\text { (rasa familier dengan } \\
\text { objek dan peristiwa) }\end{array}$ & $\begin{array}{l}\text { Sejarah seni (pan- } \\
\text { dangan ke dalam cara } \\
\text { di mana, menurut } \\
\text { kondisi sejarah yang } \\
\text { bervariasi, objek dan } \\
\text { peristiwa dinyatakan } \\
\text { alam bentuk }\end{array}$ \\
\hline $\begin{array}{l}\text { Pengetahuan tentang } \\
\text { sumber literal (rasa } \\
\text { familier dengan tema } \\
\text { dan konsep khusus) }\end{array}$ & $\begin{array}{l}\text { Sejarah tipe/jenis } \\
\text { (pandangan terha- } \\
\text { dap cara di mana, di } \\
\text { bawahkondisi sejarah } \\
\text { yang bervariasi, tema } \\
\text { dan konsep khusus } \\
\text { dinyatakan melalui } \\
\text { objek dan peristiwa) }\end{array}$ \\
\hline $\begin{array}{l}\text { Intuisi sintetis (rasa } \\
\text { familier dengan ten- } \\
\text { densi esensial dari } \\
\text { pikiran manusia); } \\
\text { dikondisikan oleh } \\
\text { psikologi personal } \\
\text { dan 'weltanschauung' }\end{array}$ & $\begin{array}{l}\text { Sejarah gejala kul- } \\
\text { tural (pandangan ke } \\
\text { dalam cara di mana } \\
\text { di bawah kondisi se- } \\
\text { jarah yang bervariasi, } \\
\text { tendensi umum dan } \\
\text { esensial dari pikiran } \\
\text { manusia dinyatakan } \\
\text { melalui tema dan } \\
\text { konsep khusus) }\end{array}$ \\
\hline
\end{tabular}

Gambar 1. Tahapan kajian Ikonografi dan Ikonologi (sumber : Panofsky, 1955:40-41)

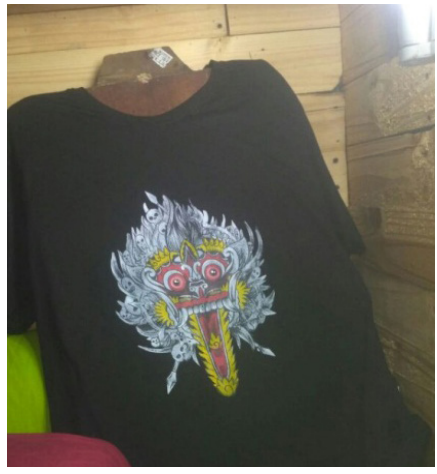

Gambar 2. Seni Lukis T-Shirt bertema Rangda (Sumber: I Nyoman Ngurah Ardika Yasa, 2018)

Pada penelitian ini, teknik pengumpulan data dilakukan dengan melakukan pengamatan langsung terhadap ilustrasi rangda karya I Nyoman Ngurah Ardika Yasa pada t-shirt lukis, melakukan kajian pustaka dan wawancara secara langsung dengan I Nyoman Ngurah Ardika Yasa. Lokasi penelitian dilakukan di Desa Abian Semal Badung tepatnya di Jalan Arja No. 11, Banjar Belawan. Dipilihnya I Nyoman Ngurah Ardika Yasa sebagai objek penelitian didasari oleh karya-karya yang dibuatnya memilih tema budaya khususnya budaya Bali.

Pra Ikonografi.

Tahap pra-ikonografi berisi tanggapan awal pada aspek tekstual yang ada dalam batasan motif artistik. Motif artistik adalah makna primer yang terbentuk dari makna faktual dan ekspresional. Makna faktual dipahami dengan mengidentifikasi bentuk yang tampak pada objek maupun perubahannya melalui aksi dan peristiwa tertentu. Hal itu dapat dilakukan dengan mengidentifikasi konfigurasi unsur-unsur bentuk murni atau membaca yang tampak seperti garis, bentuk, warna, material dan teknik, serta objek-objek representasi alami seperti manusia, binatang, tumbuhan, dan benda peralatan. Makna ekspresional dipahami dengan cara mengungkap empati dari kemampuan mengamati kebiasaan dan rasa familier terhadap objek dan peristiwa. Mengidentifikasi hubungan antara bentuk-bentuk dan peristiwa-peristiwa yang dapat menjadikan kualitas ekspresional sebagai karakter atau bahasa tubuh objek (Panofsky, 1955: 33-34).

Identifikasi unsur faktual dan ekspresional yang menyusun motif artistik pada Seni lukis T-Shirt bertemakan Rangda karya I Nyoman Ngurah Ardika dilakukan melalui pengamatan secara kasat mata atas rasa familiar terhadap suatu objek atau peristiwa. Unsur faktual diidentifikasi berdasarkan bentuk, yang meliputi warna, garis, atau tekstur yang merupakan representasi objek ilmiah (alami) (Panofsky, 1955:24).

Pada gambar diatas menunjukkan penggunaan garis lengkung bebas, garis miring, garis lengkung dan garis zig zag. Penggunaan garis lengkung bebas tersebut terlihat digunakan pada bagian mata dan tengkorak yang kecil - 


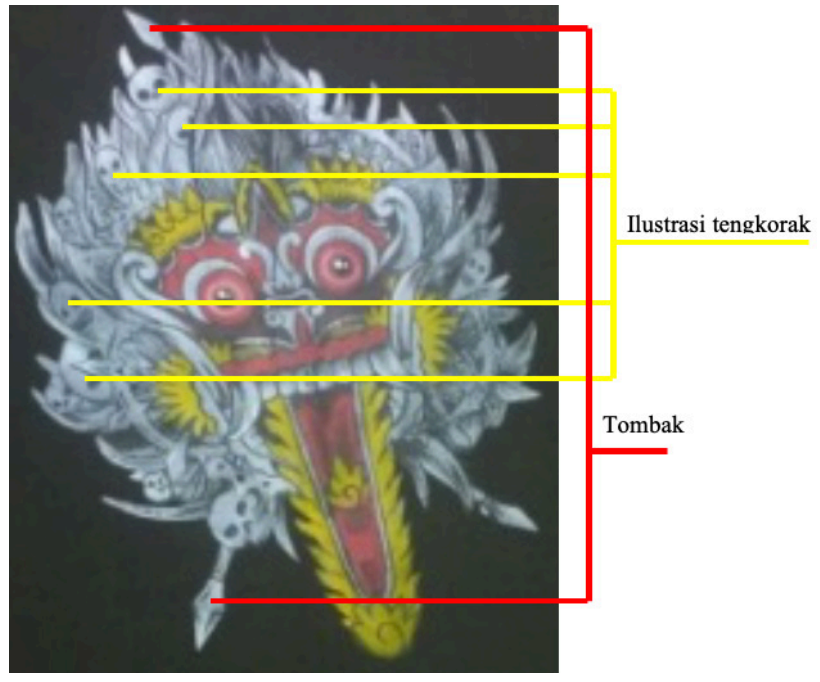

Gambar 3. Ilustrasi Rangda

kecil yang terdapat pada rambut ilustrasi rangda, penggunaan garis miring terlihat pada lidah rangda dengan garis tegak miring yang membentuk lidah dari ilustrasi rangda, garis miring digunakan pada tanduk, taring rangda dan hidung rangda, dan garis zig zag terlihat digunakan pada lidah rangda, bulu yang terdapat dibelakang taring rangda dan pada alis rangda. Penerapan ide imajinatif dapat dilihat dari dominasi penggunaan garis lengkung yang mempunyai karakteristik menimbulkan kesan pada perasaan, yaitu lemah, sensitif dan ekspresif (Pujiriyanto, 2005:88). Garis lengkung dapat memberikan keleluasaan pada seniman dalam membentuk objek sesuai dengan imajinasi. Garis merupakan cerminan kombinasi emosi yang diwujudkan melalui goresan tangan hingga membentuk objek yang sesuai dengan imajinasi dan kreativitasnya. Hal tersebut sesuai dengan yang disampaikan Kartika (2007: 36), dalam dunia seni rupa kehadiran garis bukan hanya sebagai garis, tetapi kadang sebagai simbol emosi yang diungkapkan lewat garis, atau lebih tepat disebut goresan. Goresan atau garis yang dibuat oleh seorang seniman akan memberikan kesan psikologis yang berbeda pada setiap garis yang dihadirkan, sehingga dari kesan yang berbeda maka garis mempunyai karakter yang berbeda pada setiap goresan yang lahir dari seniman.

Pada ilustrasi rangda, ide imajinatif pada bidang dapat dilihat dari bentuk rangda. Menurut I Nyoman Ngurah Ardika Yasa, wujud rangda sengaja diubah sedemikian rupa untuk memberikan perbedaan dan menciptakan ciri khas. Oleh karena itu, wujud rangda secara visual lebih menyerupai wujud raksasa. Untuk menguatkan makna rangda sebagai cerminan Dewi Durga (penguasa kuburan), I Nyoman Ngurah Ardika Yasa menambahkan objek tengkorak pada rambut.

Perubahan bentuk rangda yang divisualisasikan dengan bentuk yang lebih mirip raksasa, berawal dari ketertarikan I Nyoman Ngurah Ardika Yasa terhadap wujud misterius raksasa, yang dapat dikombinasikan dengan cerita antara kenyataan, impian dan horor. Dalam kebanyakan cerita, raksasa digambarkan dengan bentuk yang menyimpang dari makhluk hidup normal lainnya, hal ini memberi keleluasan dalam mengembangkan imajinasi, dan dapat berimajinasi lebih bebas untuk menciptakan bentuk - bentuk imajinatif.

Perubahan bentuk rangda pada ilustrasi rangda karya I Nyoman Ngurah Ardika Yasa, dilakukan dengan mendeformasi struktur - struktur identik rangda. Perubahan bentuk rangda paling terlihat pada perubahahan bentuk rambut rangda yang dibuat dengan berhiaskan tengkorak dan tombak. Perubahahan ini tidak lain adalah sebuah usaha untuk mempermainkan tanda pada rangda tanpa memperhatikan konteks maknanya.

Berikut adalah struktur rangda yang diubah pada ilustrasi rangda, yang ditampilkan dalam tabel 1 .

Pada ilustrasi rangda, warna hitam, merah, dan kuning dengan warna bersifat panas. Pada ilustrasi rangda, warna yang digunakan adalah dominasi hitam dengan penggunaan warna panas seperti merah dan kuning penggunaan warna panas pada bentuk ilustrasi rangda di $t$-shirt lukis diatas dapat menekankan kesan dan cerita yang divisualisasikan pada bentuk ilustrasi rangda diatas dapat memiliki arti agresif dan berbahaya sesuai dengan psikologi warna. Dalam psikologi warna, makna-makna dari warna tersebut dapat diuraikan sebagai berikut :

1. Merah mengartikan: Kekuatan, bertenaga, kehangatan, nafsu, cinta, agresif, berbahaya, semangat.

2. Kuning mengartikan: Ceria, Bahagia, Energik dan Optimis.

3. Abu-abu mengartikan: Intelek, futuristik, modis, kesenderuan, merusak.

4. Putih mengartikan; Kemurnian/suci, bersih, kecermatan, innocent (tanpa dosa), steril, kematian.

5. Hitam mengartikan: Kekuatan, seksualitas, kemewahan, kematian, misteri, ketakutan, ketidakbahagiaan, keanggunan.

Makna ekspresional dipahami dengan cara mengungkap empati dari kemampuan mengamati kebiasaan dan rasa familier terhadap objek dan peristiwa. Mengidentifikasi hubungan antara bentuk-bentuk dan peristiwa-peristiwa dapat menjadikan kualitas ekspresional sebagai karakter atau bahasa tubuh objek (Burhan, 2013). Berdasarkan wawancara dengan I Nyoman Ngurah Ardika Yasa pada tanggal 15 Juni 2018, dikatakan bahwa raksasa merupakan sebuah representasi tentang keliaran dalam berkarya. Dia merasakan bebas untuk mengekspresikan kreativitas dan imajinasinya dalam menggambarkan sebuah objek tersebut termasuk dalam menggambarkan wujud rangda. Menurutnya, perubahahan bentuk rangda yang divisualisasikan dengan bentuk yang lebih mirip raksasa, berawal dari ketertarikannya terhadap wujud misterius raksasa, yang dapat dikombinasikan dengan cerita tentang kenyata- 
Tabel 1. Perubahan Wujud Pada Ilustrasi Rangda

\begin{tabular}{|c|c|c|}
\hline Struktur Rangda & Wujud Tradisi & $\begin{array}{c}\text { Karya I Nyoman Ngurah Ardika } \\
\text { Yasa }\end{array}$ \\
\hline $\begin{array}{c}\text { kisualisasi secara } \\
\text { keseluruhan }\end{array}$ & & \\
\hline Mata Melotot & & \\
\hline
\end{tabular}

an, impian dan horor. Kebanyakan cerita-cerita yang ada, pada umumnya raksasa digambarkan dengan bentuk yang menyimpang dari makhluk hidup normal lainnya. Hal ini memberi keleluasan dalam mengembangkan imajinasi yang lebih bebas untuk menciptakan bentuk - bentuk imajinatif. Pengalaman hidup sebagai orang Bali yang tidak bisa lepas dari aneka ragam bentuk kesenian dan kebiasaan orang Bali yang mempercayai dua sisi dunia (skala dan niskala) serta pengalamannya yang gemar pada karakter dan cerita daerah Bali, memberikan ruang bagi I Nyoman Ngurah Ardika Yasa untuk berimajinasi seluas-luasnya terhadap peristiwa maupun wujud diluar nalar manusia. Menurutnya, kebiasaan dari kecil berimajinasi terhadap unsur-unsur budaya Bali yang beragam seperti warna, bentuk, spirit, cerita dan nuansa mistis telah memberikan inspirasi tersendiri bagi karya-karyanya. Masyarakat Bali memiliki kepercayaan tentang dunia lain termasuk dunia mistis dan hidup berdampingan dengannya menyebabkan
I Nyoman Ngurah Ardika Yasa sering memiliki bayangan tentang hal tersebut. Bentuk-bentuk mistis seperti barong, rangda hingga celuluk telah memberikan imajinasi pada karyanya. Dia juga mengatakan bahwa setiap daerah di Bali tentunya memiliki unsur-unsur mistis yang sangat menarik untuk dikembangkan. Meskipun secara visual ilustrasi karya I Nyoman Ngurah Ardika Yasa telah mengalami proses perubahan wujud dan memiliki berbagai penggayaan didalamnya, namun hal tersebut justru menjadi ciri khas yang melekat pada karyanya. Pada wawancara tanggal 19 Oktober 2018, I Nyoman Ngurah Ardika Yasa menyatakan bahwa untuk melukiskan hal-hal yang pernah dialami pada masa lalu, tidak perlu divisualisasikan secara spesifik dan detail, yang terpenting adalah rasa yang dialami bisa kembali dinikmati dengan wujud gambar atau ilustrasi. 


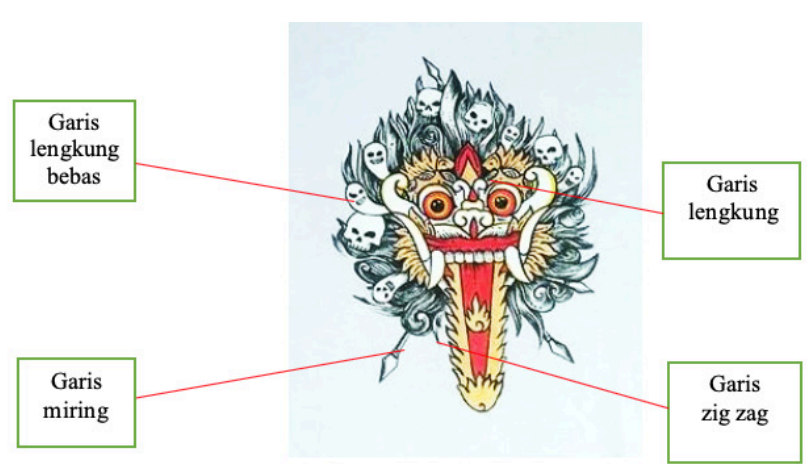

Gambar 4. Garis pada ilustrasi rangda

Imajinasi adalah proses pengolahan image secara internal yang merupakan hasil integrasi antara persepsi yang diperoleh melaluui pengalaman stimuli luar dengan memori dimana memori dan stimuli luar diperoleh melalui proses learning by doing yang mengasah keterampilan dengan melibatkan anggota badan yang masuk ke ranah psikomotorik. Imajinasi inilah yang mengawali munculnya ide-ide unik yang mengarah pada pembentukan proses kreativitas (Rizaldi, 2012). I Nyoman Ngurah Ardika Yasa menjelaskan pandangannya tentang imajinasi sebagai sebuah dunia yang bebas dan tanpa aturan. Imajinasi berarti kebebasan berkarya dan tidak terpaku pada aturan (wawancara pada tanggal 15 Juni 2018). Berdasarkan pandangannya tersebut, I Nyoman Ngurah Ardika Yasa merupakan sosok seniman yang memandang imajinasi merupakan faktor yang penting dalam berkarya. I Nyoman Ngurah Ardika Yasa tidak suka dibatasi oleh berbagai aturan yang dapat mengikat kreativitasnya dalam memvisualisasikan sebuah objek yang ingin diciptakan. Karya - karya yang telah diciptakannya adalah sebuah jawaban dari kegelisahannya untuk keluar dan mencoba mendobrak pakem bentuk yang selama ini membatasi kreativitas dalam berkarya. Baginya yang terpenting dalam proses berkarya adalah kreativitas dan memvisualisasikannya dengan gaya sendiri.

Ilustrasi rangda karya I Nyoman Ngurah Ardika Yasa diciptakan tidak dengan mengedepankan nilai keindahan secara konvensional, namun berdasarkan imajinasi atas rasa dan pengalaman estetis yang diterimanya pada masa yang lalu. Pada karyanya, I Nyoman Ngurah Ardika Yasa menggambarkan wujud rangda dengan penggayaan bentuk melalui penyederhanaan, sehingga karakter rang$d a$ terlihat berbeda dengan wujud rangda secara tradisi. I Nyoman Ngurah Ardika Yasa (wawancara pada 17 Februari 2018) mengatakan bahwa pengubahan bentuk sengaja dilakukan untuk menjawab kebosanannya atas keseragaman, mencoba membantah kaidah - kaidah bentuk tradisi dan ingin menciptakan sebuah perbedaan. Melalui karyanya, I Nyoman Ngurah Ardika Yasa menginginkan timbulnya beragam interpretasi positif dari penikmat. Hal tersebut menandakan bahwa ilustrasi rangda karya I Nyoman Ngurah Ardika Yasa lahir dari paradigma berpikir postmodern. Seperti yang tampak pada ilustrasi rangda pada gambar

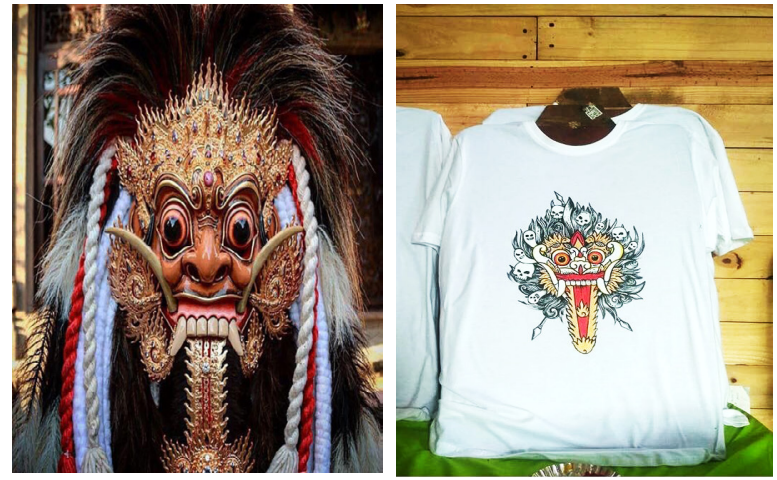

Gambar 5. Perbandingan bentuk rangda tradisional dan karya I Nyoman Ngurah Ardika Yasa.

2, Ilustrasi yang terlihat menggambarkan sosok wajah yang memerah dengan mata terbelalak dan lidah terjulur mengekspresikan tentang kengerian yang tampilkan oleh seniman. Rambut yang melilitkan tengkorak manusia dengan tombak yang terkesan keluar dari kepala mengekspresikan tentang kematian manusia. Secara keseluruhan dapat dikatakan bahwa ilustrasi yang digambarkan merupakan sebuah komunikasi bahwa Rangda merupakan sosok yang akan membawa kematian bagi manusia.

\section{Analisis Ikonografi}

Tahapan selanjutnya ini adalah mengidentifikasi makna sekunder yang dihubungkan dengan tema dan konsep. Pada tahapan ini digunakan teori Roland Barthes untuk mengungkap lambang yang ada pada karya tersebut. Mitos yang hadir sebagai petanda dalam karya selanjutnya dihubungkan dengan tema dan konsep yang tersirat. Mitos disini memiliki perbedaan pengertian secara umum. Mitos, menurut Roland Barthes (Kurniawan, 2001:84) adalah sebuah sistem komunikasi yang dengan demikian dia adalah sebuah pesan. Mitos kemudian tak mungkin dapat menjadi sebuah obyek, sebuah konsep, atau sebuah ide, karena mitos adalah sebuah mode penandaan yakni sebuah bentuk. Mitos sebagai sebuah bentuk tidak dibatasi oleh obyek pesannya, tetapi dengan cara apa mitos menuturkan pesan itu. Dengan demikian ada batas-batas formal dari mitos, tetapi tak ada batasan yang "subtansial". Kuno atau tidak, mitologi hanya dapat memiliki sebuah landasan sejarah, yakni tipe tuturan yang terpilih dari sejarah, dan dia tak mungkin dapat berkembang dari "hakikat" benda-benda. Untuk itu diperlukan pengamatan dengan melihat hubungan bentuk dan tema serta konsep dalam kebiasaan pengalaman praktis.

"Rangda" telah menjadi mitos yang ada pada masyarakat Bali. Masyarakat Bali mengenal rangda sebagai sosok ratu para leak yang menyeramkan dimana menurut mitos suka menculik anak kecil dan memakannya. Rangda berasal dari bahasa Jawa Kuno dari kata Randa yang artinya "Janda". Menurut sejarahnya, Rangda berarti janda yaitu nama lain dari Calonarang, seorang janda dari desa Girah (Dirah) yang mempraktekkan ilmu hitam (pengeleakan) (Karthadinata, 2006). Ia juga disebut Randaning Dirah dan 
wujud mukanya berupa topeng yang sangat menakutkan. Taringnya mencuat keluar, mata melotot, lidah menjulur kebawah, dan rambut lebat memanjang. Rangda ini dapat dipakai untuk menokohkan watak yang angker, sakti, dan jahat. Jenis-jenis Rangda terbagi menjadi 3 (tiga) yaitu:

1. Nyinga yaitu bentuk muka rangda ini menyerupai singa dan memiliki wajah sedikit menonjol ke depan. Sifat Rangda ini adalah galak dan buas.

2. Nyeleme yaitu bentuk muka Rangda ini menyerupai wajah manusia dan sedikit melebar. Sifat Rangda ini adalah berwibawa dan angker.

3. Raksasa yaitu bentuk muka Rangda ini menyerupai raksasa pada umumnya. Rangda ini umumnya menyeramkan.

Berbagai symbol yang ada pada Rangda memiliki makna sebagai berikut (Ferry, 2018):

1. Lidah menjulur panjang memiliki arti selalu lapar dan ingin selalu memangsa.

2. Lidah berapi-api melambangkan pembakaran tiada ampun.

3. Mata melotot melambangkan sifat kemurkaan dan bengis.

4. Taring panjang melambangkan sifat kejam dan buas.

5. Simbol api di kepala melambangkan sinar kesaktian

Ilustrasi rangda karya I Nyoman Ngurah Ardika Yasa divisualisasikan dengan wujud yang telah diubah sedemikian rupa, sehingga menghasilkan permainan tanda yang membuatnya tidak memiliki makna yang pasti atau tunggal. Makna denotasi pada ilustrasi rangda karya I Nyoman Ngurah Ardika Yasa adalah sosok rangda yang sudah dideformasi dengan rambut yang berdiri berhiasan tengkorak, gelembung udara bergambar wajah dan tombak sebanyak empat, mata mendelik dan diatas mata dihiasi bulu berwarna kuning, dibawah mata terdapat dua tanduk, gigi bertaring tajam dan lidah menjulur berhiaskan api. Warna yang digunakan pada ilustrasi rangda karya I Nyoman Ngurah Ardika Yasa adalah merah pada warna wajah dan lidah rangda dan kuning pada api yang menghiasi lidah dan bulu pada atas mata dan pinggiran taring rangda. Makna konotasi ilustrasi rangda karya I Nyoman Ngurah Ardika Yasa adalah penggambaran sosok rangda yang dilihat dari rambut mengembang berhiaskan tengkorak dan empat tombak memberikan kesan bahwa rangda adalah sosok yang sebagai penguasa kuburan. Selain tengkorak, terdapat juga gelembung udara di rambut rangda yang terdapat ilustrasi wajah yang menyerupai roh, roh adalah makhluk halus penghuni kuburan sehingga menambah kesan rangda sebagai penguasa dan penjaga kuburan. Warna merah pada wajah ilustrasi rangda menunjukan bahwa sifat amarah rangda yang sangat memuncak, dan warna kuning pada bulu diatas mata rangda mengambarkan rangda sebagai sosok keagungan.

Ekspresi adalah penyaluran emosi estetis empatis maupun emosi estetis formalistis oleh creator melalui objek estetis agar dapat membangkitkan pengalaman estetis spectator (Junaedi, 2016:150). Dalam kamus besar bahasa Indonesia, ekspresi diartikan sebagai pengungkapan atau proses menyatakan (yaitu memperlihatkan atau menyatakan maksud, gagasan, perasaan, dan sebagainya). Makna ekspresi pada ilustrasi rangda, tidak hanya tercermin dari cara I Nyoman Ngurah Ardika Yasa dalam mengungkapkan perasaannya kedalam bentuk ilustrasi. Makna ekspresi juga divisualisasikan secara ekspresif, terlihat pada tampilan rambut, topeng, lidah dan segala hiasan yang yang menghiasi rangda tersebut terlihat rambut rangda yang dihiasi tengkorak dan bentuk pepatran yang dihiasi tombak sebanyak empat, pada topeng dibuat dengan bentuk pepatran yang sangat mendominasi terlihat pada bagian pipi rangda dihiasi tanduk yang menyerupai bentuk pepatran, lidah rangda yang dibentuk bergerigi yang diumpamakan seperti api dan mata yang digambarkan melotot tidak menghilangkan ciri khas rangda pada umumnya.

Promosi dapat diartikan sebagai upaya untuk memperkenalkan sesuatu kepada pihak lain (Liliweri, 2011:494). Menurut I Nyoman Ngurah Ardika Yasa, pada ilustrasi rangda, makna promosi dapat dilihat dari tujuan penciptaannya yaitu upaya memperkenalkan budaya Bali masa lalu kepada khalayak dengan sudut pandangan yang lebih kekinian. Secara visual, makna promosi budaya Bali tampak nyata dengan adanya $t$-shirt lukis yang mengangkat tema budaya Bali. Selain itu, T-shirt seni lukis bertemakan rangda juga telah menyampaikan sebuah pesan bahwa $\mathrm{Pu}-$ lau Bali mempunyai berbagai macam - macam kesenian daerah. Kesenian-kesenian daerah Bali yang terkenal dengan kesakralannya dan keindahan yang luar biasa, membuatnya menjadi layak untuk dikunjungi sebagai salah satu destinasi pariwisata. Selanjutnya, menurut I Nyoman Ngurah Ardika Yasa makna promosi budaya Bali juga diwujudkan dengan desain $t$-shirt lukis ini dinilai secara implisit menyiratkan makna kesakralan pulau Bali. Pada ilustrasi rangda, visualisasi yang tampak merupakan sebuah upaya untuk mempromosikan budaya Bali sebagai sebuah daerah dengan kekayaan budaya dan kesenian yang sangat tinggi.

\section{Interpretasi Ikonologis}

Seni budaya Bali sudah cukup terkenal tidak hanya oleh masyarakat lokal dan nasional tetapi juga oleh masyarakat dunia. Berbagai jenis tarian, musik dan seni rupa ada di Bali telah banyak diketahui oleh masyarakat. Salah satunya adalah rangda. Rangda sebagai salah satu bentuk seni dan budaya Bali telah banyak dipentaskan pada acara-acara tertentu di Bali. Rangda sebagai sebuah bentuk budaya sakral yang di Bali, telah berubah bentuk sebagai akibat dari perkembangan jaman yang ada. Kebudayaan postmodern telah banyak memberikan pengaruh terhadap seni dan budaya Bali, salah satunya adalah pementasan calonarang yang merupakan induk dari pementasan rangda.

Kebudayaan didefinisikan pada konsep "kebudayaan terdiri dari pola-pola perilaku yang eksplisit dan implisit dari 
mana pola-pola tersebut diperoleh dan ditularkan dengan bantuan simbol sebagai prestasi khas kelompok manusia, termasuk perwujudan kelompok manusia dan artefak (Liliweri, 2014:5). Wujud kebudayaan menurut Ogburn dan Nimkoff (dalam Liliweri, 2014:12), terbagi menjadi dua yaitu kebudayaan material dan non-material. Kebudayaan material merupakan bukti fisik tentang keberadaan, identitas, karakteristik dari suatu kelompok atau komunitas suatu masyarakat tertentu. Kebudayaan non-material terdiri dari benda-benda abstrak yang tidak berwujud, misalnya adat istiadat, tradisi, kebiasaan, perilaku, sikap, kepercayaan, bahasa, sastra, seni, hukum, agama dan lain-lain.

Identitas secara etimologi berasal dari kata identity, yang berarti 1) kondisi atau kenyataan tentang sesuatu yang sama, suatu keadaan yang mirip satu sama lain; 2) kondisi atau fakta tentang sesuatu yang sama diantara dua orang atau dua benda; 3) kondisi atau fakta yang menggambarkan sesuatu yang sama diantara dua orang atau dua kelompok atau benda; 4) pada tataran teknis, pengertian etimologis diatas hanya sekedar menunjukkan tentang suatu kebiasaan untuk memahami identitas dengan kata "identik" (Liliweri, 2009:69). Identitas tidak hanya memberikan makna tentang pribadi seseorang, tetapi lebih jauh dari itu, menjadi ciri khas seseorang. Sehingga identitas budaya dapat diartikan sebagai ciri khas budaya yang dimiliki oleh sekelompok orang. Rangda sebagai salah satu budaya yang dimiliki oleh masyarakat Bali telah menjadi identitas budaya. Identitas budaya ini merupakan sebuah bentuk dari kepercayaan yang dimiliki oleh masyarakat Bali tentang dunia mistis. Seperti diungkapkan oleh I Nyoman Ngurah Ardika Yasa bahwa Bali memiliki budaya yang cukup beragam. Tapi saat ini, budaya Bali telah banyak mengalami perubahan akibat dari perkembangan jaman. Saat ini, perkembangan jaman sudah mengarah pada jaman postmodern. Seperti yang diungkapkan oleh Lyotard bahwa postmodern, dalam posisinya didalam modern, berupaya menyajikan sesuatu yang tidak dapat disajikan didalam penyajian itu sendiri; yang menolak pesona bentuk-bentuk indah, konsensus selera yang memungkinkan pengalaman nostalgia secara kolektif dari hal-hal yang tak terjangkau; yang mencari bentuk-bentuk penyajian baru, tidak untuk menikmatinya, tetapi untuk membangkitkan perasaan ketidakmungkinan penyajian tersebut (Piliang, 2010:102). Ciri-ciri dari postmodern (Ilham, 2018) adalah pertama, pemikiran Rosenau mengatakan secara nyata bahwa postmodernisme hadir sebagai kritik terhadap aliran modernisme yang gagal dalam memenuhi janji-janji kehidupan sosial yang lebih baik. Kedua, pemikiran postmodernisme memiliki ciri bahwa ia cenderung menolak meta-narasi, totalitas, dan pandangan-pandangan besar dunia. Artinya, postmodernisme lebih menerima penjelasan yang sangat terbatas (lokal naratif) untuk mengisi kehidupan. Ketiga, Rosenau juga mengatakan bahwa pemikiran postmodernisme cenderung melihat pada fenomena-fenomena emosional pra-modern, semisal emosi, perasaan, intuisi, refleksi, spekulasi, metafisika, tradisi, kosmologi, magis, mitos, sentimen keagamaan, dan pengalaman mistik. Keempat, Nuyen menjelaskan bahwa banyak pemikir postmodernis yang menolak gaya diskursus akademis modern yang teliti dan bernalar. Hal ini disebabkan oleh tujuan dari pengarang yang menganut aliran postmodernisme adalah mengejutkan dan mengagetkan pembaca dengan logika-logika argumentatif.

Jika diamati secara seksama, ilustrasi berupa rangda menggunakan gaya visual postmodern. Gaya postmodern adalah hilangnya batas seni antara seni dan kehidupan sehari-hari, tumbangnya batas antara budaya-tinggi dan budaya pop, percampuradukan gaya yang bersifat eklektik, parody, pastiche, ironi, kebermainan dan merayakan budaya "permukaan" tanpa peduli pada "kedalaman", hilangnya orisinalitas dan kejeniusan, dan akhirnya, asumsi bahwa kini seni Cuma bisa mengulang-ulang masa lalu belaka (Sugiharto, 1996:25-26). Gaya postmodern yang dimaksud adalah champ yaitu menolak keotentikan atau keorisinilan untuk tujuan dan kepentingannya sendiri. Champ menekankan dekorasi, tekstur, permukaan sensual, dan gaya, dengan mengorbankan isi. Champ anti sifat alamiah. Objek-objek alam, manusia, dan binatang kerap digunakan, namun secara ekstrim dideformasikan-dibuat lebih kurus, ramping, jangkung atau secara ekstrim dibuat lebih gendut, besar atau lebar (Piliang, 2010:192). Secara tradisi, rangda dikatakan adalah sebagai bentuk dari seorang wanita dengan rambut acak-acakan, memiliki kuku-kuku panjang, lidah yang menjulur panjang, dan payudara yang panjang. Wajahnya menakutkan dan memiliki taring-taring yang panjang dan tajam. Ilustrasi rangda karya I Nyoman Ngurah Ardika Yasa diciptakan tidak dengan mengedepankan nilai keindahan secara konvensional, namun berdasarkan imajinasi atas rasa dan pengalaman estetis yang diterima pada masa yang lalu. Pada karyanya wujud rangda digambarkan dengan penggayaan bentuk melalui penyederhaan dan deformasi bentuk, sehingga karakter rangda terlihat berbeda dengan wujud rangda secara tradisi. Sebagaimana dijelaskan Jenks (dalam Pawitro) mengapa gerakan arsitekstur postmodernisme hadir yaitu karena merasa bosan dengan tampilan-tampilan bangunan bergaya modern yang cendrung sederhana dan seragam, merasa bosan dengan tampilan bentuk bangunan yang terkungkung oleh prinsip efisiensi dan efektivitas, menghilangnya identitas tempat atau lokasi karena penekanan bangunan yang harus berbentuk kubisme dan geometric dan juga akibat penetapan/ pemilihan bentuk-bentuk yang rasional-goemetris tanpa melihat pada aspek sejarah atau lokalitas. Kemudian prinsip-prinsip ini mulai digugat oleh aliran arsitektur postmodernisme (Pawitro, 2010).

\section{SIMPULAN}

Kajian ikonografi pada seni lukis $t$-shirt karya I Nyoman Ngurah Ardika Yasa terbagi menjadi tiga tahap yaitu pra 
ikonografi (pre iconographical description), analisis ikonografi (iconographical analysis) dan interpretasi ikonologis (iconological interpretation). Kajian ikonografi yang digunakan ini untuk melihat makna dari seni lukis t-shirt karya I Nyoman Ngurah Ardika Yasa. Makna yang muncul pada karya seni lukis t-shirt tersebut adalah makna faktual dan ekpresional yang membentuk motif artistik, makna konotasi dan denotasi dari teori Roland Barthes, makna ekpresi, makna promosi, makna postmodern. Pada makna faktual dapat dilihat bahwa garis-garis yang digunakan lebih banyak menggunakan garis-garis lengkung. Selain itu, garis miring, dan garis zigzag. Makna ekspresional dapat dilihat dari Ilustrasi yang menggambarkan sosok wajah yang memerah dengan mata terbelalak dan lidah terjulur mengekspresikan tentang kengerian yang tampilkan oleh seniman. Rambut yang melilitkan tengkorak manusia dengan tombak yang terkesan keluar dari kepala mengekspresikan tentang kematian manusia. Secara keseluruhan dapat dikatakan bahwa ilustrasi yang digambarkan merupakan sebuah komunikasi bahwa Rangda merupakan sosok yang akan membawa kematian bagi manusia.

Makna denotasi pada ilustrasi rangda karya I Nyoman Ngurah Ardika Yasa adalah sosok rangda yang sudah dideformasi dengan rambut yang berdiri berhiasan tengkorak, gelembung udara bergambar wajah dan tombak sebanyak empat, mata mendelik dan diatas mata dihiasi bulu berwarna kuning, dibawah mata terdapat dua tanduk, gigi bertaring tajam dan lidah menjulur berhiaskan api. Warna yang digunakan pada ilustrasi rangda karya I Nyoman Ngurah Ardika Yasa adalah merah pada warna wajah dan lidah rangda dan kuning pada api yang menghiasi lidah dan bulu pada atas mata dan pinggiran taring rangda. Makna konotasi ilustrasi rangda karya I Nyoman Ngurah Ardika Yasa adalah penggambaran sosok rangda yang dilihat dari rambut mengembang berhiaskan tengkorak dan empat tombak memberikan kesan bahwa rangda adalah sosok yang sebagai penguasa kuburan. Selain tengkorak, terdapat juga gelembung udara di rambut rangda yang terdapat ilustrasi wajah yang menyerupai roh, roh adalah makhluk halus penghuni kuburan sehingga menambah kesan rangda sebagai penguasa dan penjaga kuburan. Warna merah pada wajah ilustrasi rangda menunjukan bahwa sifat amarah rangda yang sangat memuncak, dan warna kuning pada bulu diatas mata rangda mengambarkan rangda sebagai sosok keagungan.

Makna ekspresi juga divisualisasikan secara ekspresif, terlihat pada tampilan rambut, topeng, lidah dan segala hiasan yang yang menghiasi rangda tersebut terlihat rambut rangda yang dihiasi tengkorak dan bentuk pepatran yang dihiasi tombak sebanyak empat, pada topeng dibuat dengan bentuk pepatran yang sangat mendominasi terlihat pada bagian pipi rangda dihiasi tanduk yang menyerupai bentuk pepatran, lidah rangda yang dibentuk bergerigi yang diumpamakan seperti api dan mata yang digambar- kan melotot tidak menghilangkan ciri khas rangda pada umumnya. Makna promosi budaya Bali juga diwujudkan dengan desain $t$-shirt lukis ini dinilai secara implisit menyiratkan makna kesakralan pulau Bali. Pada ilustrasi rangda, visualisasi yang tampak merupakan sebuah upaya untuk mempromosikan budaya Bali sebagai sebuah daerah dengan kekayaan budaya dan kesenian yang sangat tinggi. Makna postmodern yang dimaksud adalah champ yaitu menolak keotentikan atau keorisinilan untuk tujuan dan kepentingannya sendiri. Champ menekankan dekorasi, tekstur, permukaan sensual, dan gaya, dengan mengorbankan isi. Pada karya I Nyoman Ngurah Ardika Yasa wujud rangda digambarkan dengan penggayaan bentuk melalui penyederhaan dan deformasi bentuk, sehingga karakter rangda terlihat berbeda dengan wujud rangda secara tradisi.

\section{DAFTAR PUSTAKA}

Burhan, M. A. (2013). Ikonografi dan Ikonologi Lukisan Djoko Pekik : "Tuan Tanah Kawin Muda". Panggung Vol. 23 No. 3, September 2013, 236.

Ferry, K. (2018, 05 22). Rangda dalam Tari Bali. Retrieved from balinese gamelan \& dance article from kadek ferry dan mayumi: https://balitaksu.com/tari-rangda-id

Ilham, I. (2018). PARADIGMA POSTMODERNISME; SOLUSI UNTUK KEHIDUPAN SOSIAL ? : Sebuah pandangan Sebuah Pandangan Teoritis Dan Analitis Terhadap Paradigma Postmodernisme. Jurnal Sosiologi USK (Media Pemikiran \& Aplikasi), 12 (1), 1 - 23.

Junaedi, D. (2016). Estetika: Jalinan Subjek, Objek, dan Nilai. Yogyakarta: ArtCiv.

Karthadinata, D. M. (2006). Barong dan Rangda: Perkembangan, Proses Pembuatan, dan Sakralisasi, serta Pesan-Pesan Budaya dalam Penampilannya sebagai Kesenian Tradisional Bali (Disertasi Doktoral). Semarang: Universitas Negeri Semarang.

Kartika, D. S. (2007). Kritik Seni. Bandung: Rekayasa Sains.

Kurniawan. (2001). Semiologi Roland Barthes. Magelang: IndonesiaTera.

Liliweri, A. (2009). Makna Budaya dalam Komunikasi Antarbudaya. Yogyakarta: Penerbit LKiS.

(2011). Komunikasi: Serba Ada Serba Makna. Jakarta: Kencana.

(2014). Pengantar Studi Kebudayaan. Bandung: Penerbit Nusa Media. 
Panofsky, E. (1955). Meaning of The Visual Arts. New York: Doubleday Anchor Books.

Pawitro, U. (2010). Fenomena Postmodernisme dalam Arsitektur Abad ke-21. Jurnal Itenas Rekayasa, 14(1), 40-48.

Piliang, Y. A. (2010). Semiotika dan Hipersemiotika : Gaya, Kode dan Matinya Makna. Bandung: Matahari.

Pujiriyanto. (2005). Desain Grafis Komputer. Yogyakarta: CV. Andi Offset.

Rizaldi, M. (2012). Persepsi Edukasi Visual: Menilai Karya Visual dalam Desain. Ultimart, Vol. V, Nomor 1, 5567.

Sugiharto, I. B. (1996). Postmodernisme. Yogyakarta: Penerbit Kanisius. 